\title{
THE MORPHOSYNTAX OF RELATIVIZATION IN \\ CHHATHARE LIMBU: A TYPOLOGICAL PERSPECTIVE ${ }^{*}$
}

\author{
Govinda Bahadur Tambahang
}

\section{INTRODUCTION}

Chhathare is a dialect of Limbu, a Kiranti (Tibeto-Burman) language, spoken in Parts of the Dhankuta and Terhathum districts of the eastern Himalayan region of Nepal. It is, however, unintelligible to speakers of other Limbu dialects but quite interestingly, its speakers can understand other Limbu dialects.

There exist descriptive studies of relativization in other Limbu dialects, e.g. Weidert and Subba (1985), Van Driem (1987), and Ebert (1994). The Chhathare dialect of Limbu has, however, been hitherto undocumented and undescribed. This paper is an attempt to analyze the morphosyntax of relativization in Ghathare Limbu within the three typological parameters (Givo n, 20@2), viz. (i) the position of the relative clause vis-à-vis its head, (ii) the mode of expression of the relativized NP, and (iii) which grammatical relations can relativized.

\section{THE PHENOMENON}

A noun is normally modified by an adjective. For example, the adjective cukpaa modifies the noun pang in (1) and is thus a nominal modifier.

(1) haambaa cukpaa paang

that small house

"That small house"

Apart from adjective, a relative clause also functions as a nominal modifier, e.g.

(2) haambaa naapmi saa haambo te

that man who there go-3sA-non-PRET

"That man who goes there"

In this clause haambaa naapmi is a noun phrase modified by the relative clause saa haambo te. A typical relative clause consists of a head or relativized noun phrase and a relativizer or relative pronoun. The heade or relativized noun phrase is the entity modified by the relative clause. Thus, in (2) haambaa naapmi is the head or relativised noun phrase modified by the relative clause saa haambo $t e$. Relative clauses are often introduced by relativizers such as saa in (2).

The choice of the relativizers depends on human or non-human feature of the relativized noun. Consider the examples (3a) and (3b) in this respect.

I would like to express my thanks to Prof. Dr. Yogendra Prasad Yadav for going through the

earlier version and making insightful comment on it. 


\section{THE MORPHOSYNTAX OF RELATIVIZATION}

(3)a. haambaa menche [saa-ing Laahaang-ngaa

that young woman [who-ABS laahaang-ERG

ku-sirathaaks-u]

3sEXP-like-3sP-non-PRET

"That woman whom Lahang likes"

b. haamba pu [whing-nging pe-ro-wa

that bird [which-ABS fly-CON-be-3sA-non-PRET

"That bird which is flying"

In (3a) the relativizer saa is chosen because the head noun menche is understood to be human, and human nouns as such are always relativized by such relativizer Likewise, the head noun $p u$ in $(3 b)$ is relativized by the relativizer whing as it is a non-human noun.

In addition, the choice of a relative pronoun depends on the grammatical relationship (and also case) of the relativized noun to the relative clause, as shown in (4).

(4)a. haambaa naapmi [saa-ngaa aa-saaplaa te-u]

that man [who-ERG my-book take-3sA-non-PRET]

"That man who takes my book"

b. haambaa naapmi [saa-ing aa saaplaa pi-uy-ng]

that man [who-ABS I book give-3sIO-1sA-non-PRET]

"That man whom I give my book"

In (4a) the relative clause saa-ngaa aa-saaplaa te- $u$ is modifying the head noun naapmi. The ergative relative pronoun saa-ngaa is selected and used here because the head noun naapmi is understood as the subject of the verb te- $u$ in the relative clause, and subjects of this verb are used in the ergative. Likewise, the pronoun saa-ing (whom) is appropriate in (b) because it is the object of the relative clause verb pi-uy-ng.

A relative clause has potential variation in the semantic relationship to the noun it modifies. For example, consider the sentences in (5).

(5)a. aa-bhu saa-ing kathmandu-o yung khune

my-brother who-ABS Kathmandu-LOC stay-3sA non-PRET he phenro-wa

come-3sA-CON-be-non-PRET

"My brother who stays in Kathmandu is coming".

b. aa-bhu, saa-ing kathmandu-o yung, khune phen-ro-wa

my-brother, who-ABS Kathmandu-LOC stay-3sA-non-PT he come3sA-CON-be-non-PRET

"My brother, who stays in Kathmandu, is coming".

The sentence in (5a) singals that the speaker has more than one brother. The adjective clause the referent of $a a-b h u$ from among the set of possibilities. The sentence in $(5 b)$, on the other hand, means that the speaker has only one brother or that the listener knows the precise referent of $a a-b h u$. In this case, the 
TRIBHUVAN UNIVERSITY JOURNAL, VOL. XXIV, NO. 1,

adjective clause is purely descriptive and it provides additional information about the speaker's $p h u$. Thus the first relative clause is restrictive and the second nonrestrictive.

\section{TYPOLOGICAL PARAMETERS OF RELATIVE CLAUSES}

Languages vary in the relativization strategies that they employ. In this section we demonstrate how these strategies are realized in Chhathare Limbu. The relativization strategies, we are going to discuss here, include the following:

(1) The position of the clause with respect to the head

(2) The mode of expression of the relativized NP

(3) Grammatical relations that can be relativized

Let us examine each of them in detail.

\section{THE POSITION OF THE CLAUSE WITH RESPECT TO THE HEAD}

Limbu relative clauses can vary according to the position of the clause with respect to the head. They can occur in the following positions:

(i) Prenominal

(ii) Postnominal

(iii) Headless

(iv) Internally headed

(v) Correlative

\section{Prenominal}

Relative clauses are noun modifiers and can occur in the same positions as other noun modifiers such as descriptive adjectives, numerals, etc. do. following are the examples:

(6)a. haambaa kaa-ghup-paa naapmi te-ga that AP-steal-AP man go-3sA-PRET

"That man who steals went".

b. necchi kaa-be-ba pu-ghaachi si-ya-chi

two AP-fly-AP bird-dl die-PRET-dIP

"Two birds which used to fly died."

In (6a) naapmi is a head which is modified by the adjective clause haambaa kaa-ghup-pa in the way a noun is modified by an adjective. Similarly, in (6b) the head $p u$ is modified by the adjective clause necchi kabeba. In both the sentences the adjective clauses precede the heads.

Two relative clauses can be generated from a single independent clause. For example, consider the sentences in (7).

(7)a. naapmi-ngaa yaang katt-u

man-ERG money possess-3sA non-PRET 


\section{THE MORPHOSYNTAX OF RELATIVIZATION}

"Man ahs money".

b. naapmi-ngaa katt-u-baa yaang

man-ERG possess-3sA-NML money.

"Money that a man has possessed".

c. yaang kaa-gap-paa naapmi

money AP-possess-Ap man

"Man who has possessed money".

The sentence in (7a) is an independent clause. The clauses in (7b) and (7c) are relative clauses generated from the single independent clause in (7a). In (7b) yaang is relativized and in (7c) naapmi is relativized.

\section{Postnominal}

The prenominal and postnominal positions of the relative clause in Chhathare Limbu follow the typology of the basic constituent order of the language. OV languages tend to prefer both orders while VO language almost use the postnominal relative clause. Chhathare language is an OV language and it follows both orders.

(8)a. haambaa naapmi saa paang-o yung khune tak thok-u-ro-pung

that man who house-LOC stay-3sA non-PRET he rice cook-3sA-3sP. SEQ-must

"That man who stays in the house must cook rice".

b. haambaa naapmi saa-ghaa-nga aa-ja mu-de-u khunchi yaang mu-hungu-ro-pung.

That man who-pl-ERG my-paddy 3plA-take-3sP they money 3plA-pay3sP-SEQ-must

"Those people who take my paddy must pay money".

The clause saa-ghaa-ngaa aa-jaa mu-de-u in (8b) comes after the noun phrase head and modifies it. Similarly, in (8a) the clause saa pang-o ung postmodifies the noun phrase head haambaa naapmi.

\section{HEADLESS}

Headless relative clauses are the clauses without head. This is shown in (9).

(9)a. kaa-de-baa-ghaa mu-de

AP-go-AP-pl 3plA-go-non-PT

"Those who (want to) go go".

b. yaang kaa-naak-paa-ghaa mu-daa-yaa

who house-LOC stay-3sAalso child see-3sA-SEQ-must

"Whoever stays in the house must see the child".

The clauses in (9a) and (9b) kaa-de-baa-ghaa and yaang kaa-naak-paaghaa are headless clauses whereas in (9c) saa paang-o yung-saang is a headless clauses. These clauses function as the noun phrase heads.

\section{INTERNALLY HEADED}


TRIBHUVAN UNIVERSITY JOURNAL, VOL. XXIV, NO. 1,

Internally headed relative clauses are those for which the head is within the relative clause, as shown in (10).

(10)a. aa khene lathik saaplaa pinaa [hwing-nging khene kaa-hing-hing kaa-nir-u]

I you one book give-1sA non-PT which-ABS you you-live-you read-3sP non-PRET

"I give you a book which you would read lifelong".

b. $\quad$ khune aa lithik yaang aa-byaa-ng [whing-ngaa aa thi ing-u-ng thung-u-ng] he I one rupee he-give-1sIOPT which-MED I beer buy-3sP-1sA PRET drink-3sP-3sA PRET

"He gave me one rupee by which I bought beer and drank".

In sentence (10a) the relativizer whing-ing and in (10b) whing-ngaa make the clauses in the brackets as relative clauses. The head nouns saaplaa and yaang remain within the relative clauses and are not repeated external to the relative clauses.

\section{Coreelative}

Correlative is a clause that refers to a construction, which uses a pair of connecting words.

(11)a. khene ho ho kaa-de haambo aa taa-maa maa-suk-ngaa-n you where where you-go there there I come-INF NEG-be able-1sA-NEG "I can't come to the places where you go (according to your choice)".

b. khune he he paat-u haambaa haambaa cuk-naa-baa-i he what what say-3sA-PRET that that do-should-1

"Should we do whatever he says?"

c. khene ho-laambaa kaa-daa-yaa-i haambo-i te-gaa you where-LOC you-come-2sA-PRET-EMP-there-EMP go-2sIMP "Go to the place from where you come".

d. baa paan-ing saa-ngaa kaa-laa-i khune-i silaap-pu this matter-ABS who-ERG 3sA-tell-2sPPRET-EMP him-EMP-ask2sIMP

"Ask him who told you this thing".

In (11a) ho ho correlates with haambo haambo, in (11b) he he with haambaa haambaa, in (11c) holaambaa with haambo-i and in (11d) saa-ngaa correlates with khune-i

\section{THE MODE OF EXPRESSION OF THE RELATIVIZED NP}

Relative clause can vary according to the mode of expression of the relativized NP. This parameter is sometimes called a 'case recoverability' problem. In any relative clause there must be some way of identifying the role of the referent of head noun within the relative clause. The head noun itself functions as the main clause and it always has a coreferent within the relative 


\section{THE MORPHOSYNTAX OF RELATIVIZATION}

clause. The role of that NP can be different from the role of the head noun within the clause.

(12)a. haambaa naapmi [saa-ngaa aa-saaplaa te-u]-ngaa yaang hung-u-ro-pung this man [who-ERG my-book take-3sA3sP]-ERG-money pay-3sA-3sP SEQ-must

"That man who takes my book must pay money".

b. haambaa naapmi [saa-ing aa-saaplaa pyung] -ngaa yaang hung-u-ro-pung that man [who-ABS I book give-3s IO-1sA]-ERG-money pay-3sA-3sPSEQ-must

"That man whom I give a book must pay money".

In (12a) the head noun is the subject of the main clause verb. In (12b) the head noun is still the subject of the main clause verb, but it is now the object of the relative clause verb. These clauses can be considered to be reductions of the following two structures:

(12)a. haambaa naapmi saa-ngaa [haambaa naapmi-ngaa aa-saaplaa teu] -ngaa yaang

that man who-ERG [that man-ERG may-book take-3sA3sP]-ERGmoney hung-u-ro-pung

pay-3sA-SEQ-must

"That man who takes my book must pay money".

b. haambaa naapmi saa-ing [haambaa naapmi-ing aa saapla pyung] -ngaa yaang hung-u-ro pung

that man who-ABS [that man-ABS I book-give-3sIO-IsA-non-PRET]ERG money pay-3s A3sP-SEQ-must

"The man whom I give money must pay".

The grammatical relation of the noun phrases within the relative clauses in (13a) and (13b) are identified by the use of case markers -nga for subject and ing for object. Limbu language employs a relative pronoun strategy to identify a clause as a relative clause. It constitutes a reference to the NPrel and can itself recover the role of the NPrel in the relative clause. It introduces a relative clause and can be inflected for the role of the NPrel in the relative clause. For example, consider the sentences in (14).

(14)a. haambaa naapmi [saa-ngaa yaambak maa-ju-gun] -ngaay yaang maa-gho-un that man who-ERG work NEG-do-3sA-NEG-ERG money NEG-get3sA-3sP-NEG

"That man who doesn't do work doesn't money".

b. haambaa naapmi [saa-ing yaang kaa-bi-yu] -ngaa maa-hung-u-n that man who-ABS money you-give-3sIO-PRET ERG NEG-pay3sA3sP-NEG-PRET

"That man whom you gave money didn't pay".

These examples show that the form saa takes the subject marking -ngaa when the NPrel is the subject of the RC (haambaa naapmi-ngaa yaambak 
TRIBHUVAN UNIVERSITY JOURNAL, VOL. XXIV, NO. 1,

maajugun) and takes the object marking -ing when the NPrel is the object of the relative clause. The grammatical relation of the invisible noun phrase within the bracketed clause can be made identifiable by leaving a conspicuous 'gap' in the position where the NPrel would be if it were overtly expressed. For example, consider the sentences in (15).

(15)a. baa haambaa-i naapmi be [saa-ing aa 0 aachendaa tum-u-ng] this that-EMP-man-be who-ABS I 0 yesterday meet-3sP-1sA-PRET

"This is the man whom I met yesterday".

b. baa haambaa-i paang be [whing-o aa-ccha 0 tangbe-thik yungaa] this that-EMP house is which-LOC my son year-one stay-3sA-PRET "This is the house where my son stayed for one year".

The NPrel is left out in the surface structure of the clauses (15a) and (15b) but this problem is solved by leaving a gap in the position of the NPrel. This is called the gap strategy. Chhathare Limbu, someimes, do not utilize a relativizer or relative pronoun. This is shown in the following examples:

(16)a. aa saaplaa pi-yu-ng-baa henjaa

I book give-3sIO-1sA-NML child

"The child whom I have given a book".

b. aa naat-u-ng-baa pit

I chase-esP-1sA-NML cow

"The cow which I have chased".

The adjective clauses in (16a) and (16b) are relative clauses without a relativizer and relative pronoun.

\section{GRAMMATICAL RELATIONS THAT CAN BE RELATIVIZED}

Grammatical relations can be relativized with a relative clause strategy. Limbu allows relativization on various positions such as subject, direct object, indirect object, possessive and different adjunct positions. They are exemplified as follows:

\section{SUBJECT POSITION}

(17)a. aa haambaa naapmi-ing cit-u-ng saa-ngaa aa-yaang-ing I that man-ABS dislike-esP-1sEXP non-PRET who-ERG my money ABS maa-hung-u-n

"I dislike that man who doesn't pay my money".

b. aa hammbaa naapmi-ing cit-u-ng saa-ngaa aa-yaang-ing khutt-u I that man-ABS dislike-3sP-1sEXP non-PRET who-ERG my-moneyABS steal-3sA-3sP non-PRET

"I dislike that man who steals money".

c. I haambaa pit-ning te?-yu-ng whing-ngaa pit-nu yarik aa-bi I that cow-ABS take-3sP-1sA non-PRET which-ERG milk much 3sAgive-1Pl-IO non-PRET

"I take that cow which gives us much milk". 


\section{THE MORPHOSYNTAX OF RELATIVIZATION}

\section{DIRECT OBJECT POSITION}

(18)a. aa haambaa naapmi-ing cit-u-ng saa-ing khune aachhendaa laps-u

I that man-ABS dislike-esEXP-1sA who-ABS he yesterday beat-3sA3sP PRET

"I dislike that man whom he beat yesterday".

b. khune hambaa paang-o yung whing-ing aa-pphaang-ngaa me?lindaa saks-u

he that house-LOC stay-3sAB non-PRET which-ABS my-uncle-ERG last year sell-3sA-3sP-PRET

"He stays in that house which my uncle sold last year".

c. raam-ngaa baa saaplaa khob-u whing-ing naapmi-ngaa khaam-o laaptheu-aang-waa-haa

Ram-ERG this paper pick-3sA-3sP PRET which-ABS man-ERG ground-LOC throw-3sA-3sP-PRET-SEQ be-PT

"Ram picked up this paper which a man had thrown".

\section{INDIRECT OBJECT POSITION}

(19)a. aa haambaa naapmi-ing tum-u-ng saa-ing aa aachendaa yaang pi-yu-ngang waa-haa

I that man-ABS meet-3sP-1sA who-ABS I yesterday money give-3sIO1sA-PF-be-PRET

"I met that man whom I had given money".

b. khune haambaa waamaa-ing ser-u whing-ing aa aachendaa yaang pi-yung-ang waa-haa

he that hen-ABS kill-3sAS-PRET which-ABS I yesterday food give3sIO-1sAS-PF-be-PRET

"He killed that hen to which I gave food yesterday".

c. khene haambaa paang-o kaayung whing-ing aa me?lindaa khene sang-na aang waaha

you that house-LOC you-live which-ABS I last year you sell-2sID-1sAPF-be-PRET

"You live in that house which I had sold you last year".

\section{POSSESSIVE POSITION}

Possessors can be relativized in the Chhathare Limgu using the more explicit relative pronoun strategy.

(20)a. aa haabaa naapmi-ing cit-u-ng [saang ku-baang nubaa maa-juk-nen] I that man-ABS dislike-3s P-1sEXP non-PRET whose-3sPOSS-house good NEG3s-be-NEG

"I dislike that man whose house is not good".

b. khune haambaa koco-ing maa-de-un [whing-ngaang ku-haa-ghaa nubaa mu-hop] 
TRIBHUVAN UNIVERSITY JOURNAL, VOL. XXIV, NO. 1,

he that dog-ABS NEG-take-3sA-3sP non-PRET whose 3sPOSS-tooth-pl good are not

"He does not take that dog whose teeth are not good".

In (20a) the bracketed clause is a relative clause and the possessive personal pronoun saang is a relativizer and in (20b) the relative clause in the bracket contains non-personal pronoun whing-ngaang as a relativizer.

\section{ADJUNCT POSITIONS}

\section{a. Manner}

Adverbial clauses specify the manner in which the action the verb describes is carried out. It is usually expressed by -ngang. For example,

(21)a. aa haambaa naapmi taar-u-ng [saa-ngaa nurik-ngaang yaambak-ing cug-u]

I that man bring-3sOBJ-1sSUB non-PT who-ERG good-MANN workABS do-3sSUB non-PT

"I bring that man who do work well".

b. aa aachendaa bakthambaa naapmi-ing ni-hu-ng [saa-ngaa kak-ing lip-aaro te-yu]

I yesterday such man-ABS see-3sP-1sA-PRET who-ERG load-ABS heavy-PRET-MANN take-3sA-3sP-PRET

"Yesterday, I saw such a man who took load heavily".

In (21a) the clause in the bracket is a relative clause with a relativizer saa-ngaa and the adverb nurik-aang specifies the mode of action of the verb cug$u$. Similarly, the relative clause in the bracket with the relativizer saa-ngaa contains an adverb lipparo which specifies the mode of action of the verb teyu.

b. Place

(22)a. aa haambaa paangbhe-o tek-ngaa [ho-o yarik naapmi mu-yung]

I that village-LOC go-1sA-non-PRET where-LOC many people 3plAlivenon-PRET

"I live in that village where many people live".

b. khune haambaa paang-o yung [hwing-o aa-bhu saang yung] he that house-LOC live-3sA-non-PT which-LOC my-brother also live3sA-non-PT

"He stays in that house in which his brother also lives".

c. khune haambo maa-de-nen [ho-o yaang maa-dhak-nen] he there NEG-go-3sA-NEG-non-PRET where-LOC money NEG-earnNEG

"He doesn't go there where money is not earned".

In (22a) the relative clause in the bracket contains a relativizer ho-o which indicates place, in $(22 b)$ the bracketed relative clause with the relativizer whing-o focuse the place and in (22c) the relativizer ho-o of the relative clause in the bracket indicates the place. 


\section{THE MORPHOSYNTAX OF RELATIVIZATION}

c. Time

Adverbial clauses having to do with time (when, while) are relativized in Chhathare Limbu.

(23)a. aa haambaa-khengaa kaa-ni-haa-ng [hi-khe-ngaa aa naa teb-u-ng-rowaa-haa-ng]

I that time 2sA-see-1sP-PRET when I fish catch-3sP-1sA-CON-bePRET1sA

"You saw me that time when I was catching a fish".

b. khune baa-khe-ngaa ta-haa [hikhe-ngaa khene kaa-ip-saa-rokaa-waahaa]

he this time come-3sA-PRET when you 2sA-sleep-PRET-CONT-2sAbe-PRET

"He came at this time when you were sleeping".

In (23a) and (23b) the bracketed clauses are relative clauses relativised by the relativizer hikhe-ngaa.

\section{CONCLUSION}

This analysis of relativization in Chhathare Limbu reveals a number of features of typological interest. In section 1 we presented the phenomenon of relativization in Chhathare Limbu as a nominal modifier. Section 2 analyzed the relativization in Chhathare Limbu with relation to its typological parameters. Firsty, in terms of its position with respect to its head, the relative clause in Chhathare Limbu can be prehead, posthead, headless, internally headed or correlative. Secondly, the role of a relativized NP can be different from the role of its head noun within a relative clause. Thirdly, most of the grammatical relations such as subject, direct object, indirect, and various types of adjuncts can be relativized in Chhathare relative clauses. This shows that the choice of a relativized NP in this dialect of Limbu is not governed by specific grammatical relations.

$\begin{array}{ll}\text { ABBREVIATIONS } \\ 1 & \text { First person } \\ 2 & \text { Second person } \\ 3 & \text { Third person } \\ \text { A } & \text { Agent } \\ \text { Abs } & \text { Absolutive } \\ \text { AP } & \text { Active participle } \\ \text { CON } & \text { Continuous } \\ \text { D1 } & \text { Dual } \\ \text { ERG } & \text { Ergative } \\ \text { EXP } & \text { Experiencer }\end{array}$


TRIBHUVAN UNIVERSITY JOURNAL, VOL. XXIV, NO. 1,

$\begin{array}{ll}\text { IO } & \text { Indirect object } \\ \text { LOC } & \text { Locative } \\ \text { NML } & \text { Nominalizer } \\ \text { P } & \text { Patient } \\ \text { P1 } & \text { Plural } \\ \text { S } & \text { Singular } \\ \text { SEQ } & \text { Sequential } \\ \end{array}$

\section{WORKS CITED}

Ebert, Karen H. (1994). The Structure of Kiranti Languages, Zurich: ASAS, Verlag.

Givo $\Leftrightarrow$ n, Talmy (2002). Syntax, Amsterdam: John Benjamins.

Van Driem, George (1987). A grammar of Limbu, Berlin, etc: Mouton de Gruyter.

Weidert, Alfons \& Bikram Subba (1985). Concise Limbu Grammar and Dictionary, Amsterdam: Lobster Publications. 